\title{
Boris Lyon-Caen, Boris Lyon-Caen, Du réalisme comme objection: Balzac, avril 1830
}

\section{Marco Stupazzoni}

\section{Q OpenEdition}

1 Journals

\section{Edizione digitale}

URL: http://journals.openedition.org/studifrancesi/506

DOI: $10.4000 /$ studifrancesi.506

ISSN: 2421-5856

\section{Editore}

Rosenberg \& Sellier

\section{Edizione cartacea}

Data di pubblicazione: 1 aprile 2015

Paginazione: 164-165

ISSN: 0039-2944

\section{Notizia bibliografica digitale}

Marco Stupazzoni, « Boris Lyon-Caen, Boris Lyon-Caen, Du réalisme comme objection: Balzac, avril 1830 » Studi Francesi [Online], 175 (LIX | I) | 2015, online dal 01 avril 2015, consultato il 18 septembre 2020. URL : http://journals.openedition.org/studifrancesi/506; DOI : https://doi.org/10.4000/studifrancesi. 506

Questo documento è stato generato automaticamente il 18 settembre 2020.

\section{(c) $($ ) $\odot$ EY}

Studi Francesi è distribuita con Licenza Creative Commons Attribuzione - Non commerciale - Non opere derivate 4.0 Internazionale. 


\title{
Boris Lyon-Caen, Boris Lyon-Caen, Du réalisme comme objection: Balzac, avril
} 1830

\author{
Marco Stupazzoni
}

\section{NOTIZIA}

BORIS LYON-CAEN, Du réalisme comme objection: Balzac, avril 1830, «Romantisme. Revue du XIX ${ }^{e}$ siècle», n. 162, $4^{\text {e }}$ trimestre 2013, pp. 103-112.

1 Momento fondamentale di articolazione e di veicolazione di un nuovo concetto di realismo, la pubblicazione delle Scènes de la vie privée di Balzac nell'aprile 1830 segnano un punto di svolta estetico fondamentale nella rappresentazione del reale e nella drammatizzazione dell'«ordinaire» che non hanno nulla da condividere né con «l'“imitation" au sens classique et idéaliste du terme», né con «les modifications et les consécrations ultérieures de la mouvance réaliste-naturaliste» (p. 104). Si tratta di un concetto di realismo inteso come «objection», come una nuova ermeneutica sociale e psicologica che si manifesta attraverso un «difficile et [...] inquiétant apprentissage des signes» (p. 108). Il nuovo statuto accordato a questa nuova rappresentazione della realtà implica una radicale evoluzione della figura dello scrittore romanzesco che si precisa nella duplice immagine autoriale di "peintre" e di "analyste". Nelle Scènes de la vie privée, conclude l'A., il reale, «d'abord appréhendé comme force d'objection, [...] féconde ainsi un travail d'objectivation subtil - sachant aussi bien jouer des ellipses de la nouvelle que des multiples savoirs du nouvelliste» (p. 112). 